Canadian

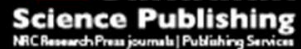

Canadian Journal of Physiology and Pharmacology Revue canadienne de physiologie et pharmacologie

\title{
Apoptosis of rat hepatic stellate cells induced by diallyl trisulfide and proteomics profiling in vitro
}

\begin{tabular}{|r|l|}
\hline Journal: & Canadian Journal of Physiology and Pharmacology \\
\hline Manuscript ID & cjpp-2015-0527.R1 \\
\hline Danuscript Type: & Article \\
\hline Complete List of Authors: & $\begin{array}{l}\text { Zhang, Ya-jie; Guangzhou Medical University } \\
\text { Zhou, Xiaoming; Guangzhou Medical University } \\
\text { Xu, Lipeng; Jinan University College of Pharmacy } \\
\text { Wang, Lulu; Shihezi University } \\
\text { Liu, Jinling; Shihezi University } \\
\text { Ye, Jing; Shihezi University } \\
\text { Qiu, Pengxin ; Sun Yat-sen University } \\
\text { Liu, Qinghua; Shihezi University }\end{array}$ \\
\hline Keyword: & $\begin{array}{l}\text { diallyl trisulfide; apoptosis; hepatic stellate cell; differentially expressed } \\
\text { proteins }\end{array}$ \\
\hline
\end{tabular}


Apoptosis of rat hepatic stellate cells induced by diallyl trisulfide and proteomics profiling in vitro

Yajie Zhang ${ }^{1}$, Xiaoming Zhou ${ }^{1}$, Lipeng $\mathrm{Xu}^{2}$, Lulu Wang ${ }^{3}$, Jinling Liu ${ }^{4}$, Jing Ye ${ }^{4}$, Pengxin Qiu ${ }^{5}$, Qinghua Liu ${ }^{6}$

${ }^{1}$ Department of Pathology, Guangzhou Medical University, Guangzhou, Guangdong

Province, China

${ }^{2}$ Institute of New Drug Research and Guangdong Province Key Laboratory of

Pharmacodynamic Constituents of TCM and New Drugs Research, Jinan University

College of Pharmacy, Guangzhou, Guangdong Province, China

${ }^{3}$ Center of Community Health Services, The First Affiliated Hospital, Medical

College, Shihezi University, Shihezi, Xinjiang Province, China

${ }^{4}$ Department of Digestive System Diseases, The First Affiliated Hospital, Medical

College, Shihezi University, Shihezi, Xinjiang Province, China

${ }^{5}$ Department of Pharmacology, Zhong-Shan Medical College, Sun Yat-sen University, Guangzhou, Guangdong Province, China

${ }^{6}$ Department of Medical Oncology, The First Affiliated Hospital of the School of Medicine, Shihezi University, Shihezi, Xinjiang Province, China

Corresponding author: Qinghua Liu M.D, Ph.D. Department of Medical Oncology, The First Affiliated Hospital of the School of Medicine, Shihezi University. Bei'er Road, Shihezi City, Xinjiang Province, China 832008, Phone: +86 993-2855-351, Fax: +86 993-2850-400, E-mail address: lqhlyd@shzu.edu.cn 


\begin{abstract}
Diallyl trisulfide (DATS), a major garlic derivative, inhibits cell proliferation and triggers apoptosis in a variety of cancer cell lines. However, the effects of DATS on hepatic stellate cells (HSCs) remain unknown. This study was aimed to analyze the effects of DATS on the cell proliferation and apoptosis, as well as the protein expression profile in rat HSCs. The rat HSCs were treated with or without 12 and 24 $\mu \mathrm{g} / \mathrm{mL}$ DATS for various time intervals. The cell proliferation and apoptosis were determined using tetrazolium dye (MTT) colorimetric assay, Bromodeoxyuridine (5bromo-2'-deoxyuridine, BrdU) assay, Hoechst 33342 staining, electroscopy and flow cytometry. Protein expression patterns in HSCs were systematically studied using two-dimensional electrophoresis and mass spectrometry. DATS inhibited the cell proliferation and induced apoptosis of HSCs in a time-dependent manner. We observed clear morphological changes of apoptotic HSCs and dramatically increased Annexin V-positive/PI negative apoptosis compared with the untreated control group. Twenty-one significant differentially expressed proteins, including 9 down-regulated proteins and 12 up-regulated proteins, were identified after DATS administration, and most of them were involved in apoptosis. Our results suggest that DATS is an inducer of apoptosis in HSCs, and several key proteins may be involved in the molecular mechanism of apoptosis induced by DATS.
\end{abstract}

Key words: Diallyl trisulfide; Apoptosis; Hepatic stellate cells; Differentially expressed proteins 


\section{Introduction}

Liver fibrosis is a disease affecting an estimated 100 million people worldwide (Curry 2013; Morgan et al. 2013). Liver fibrosis and associated cirrhosis are caused by chronic viral hepatitis, alcohol toxicity, autoimmune diseases and hereditary metabolic disorders. It is now generally accepted that a central pathologic mechanism underlying liver fibrosis is the generation and proliferation of smooth muscle $\alpha$-actin ( $\alpha$-SMA)-positive myofibroblasts of periportal and perisinusoidal origin that arise as a consequence of the activation of hepatic stellate cells (HSCs) and other cell types, such as periportal fibroblasts (Bataller and Brenner 2005; Senoo 2004). HSCs are critically involved in the development of liver fibrosis because they are responsible for the excessive deposition of extracellular matrix (ECM) proteins in the liver. Therefore, it is critical to reduce the number of activated HSCs for the reversibility of liver fibrosis (Yin et al. 2013). There are three major pathways that may help eliminate the activated HSCs: apoptosis, senescence or reversal to an inactivated phenotype. In recent years, Induction of apoptosis as elimination of HSCs has been suggested to be effective in the control of hepatic fibrosis (Fallowfield 2011; Tacke and Weiskirchen 2012). Diallyl trisulfide [DATS; 3-(prop-2-enyltrisulfanyl)prop-1ene, $\mathrm{CH}_{2}=\mathrm{CHCH}_{2}-\mathrm{SSS}-\mathrm{CH}_{2} \mathrm{CH}=\mathrm{CH}_{2}$, (Molecular weight, 178.20)], a characteristic flavor produced by garlic, contains three sulfur atoms with two allyl groups. Previous studies also indicated that garlic had multiple liver protection properties (Borek 2001; Chen et al. 2012; Zeng et al. 2008). The underlying mechanisms consist of hepatocyte protection including TGF- $\beta 1$ inhibition and reduced hepatic oxidative stress (D'Argenio et al. 2013; Zhu et al. 2014). DATS has been reported to inhibit proliferation of cultured cancer cells by causing cell cycle arrest and inducing apoptosis (Zhang et al. 2007). A recent study also suggested that DATS could cause cell cycle arrest and induce apoptosis associated with reactive oxygen species (ROS) production in breast cancer cells (Chandra-Kuntal et al. 2013). However, it still remains unclear whether DATS could induce apoptosis of HSCs or not.

To determine suitable doses of DATS for our study, we carefully reviewed the available data. Several previous studies had reported that DATS at a concentration range of 10 to $100 \mu \mathrm{M}$ induced apoptosis in several human cancer cells (Wang et al. 2010; Xiao et al. 2009). In this study, we first explored the effects of DATS at two concentrations (12 and $24 \mu \mathrm{g} / \mathrm{mL}$, equivalent as 67.5 and $135 \mu \mathrm{M})$ on apoptosis in rat HSCs. We observed that the exposure to $24 \mu \mathrm{g} / \mathrm{mL}$ DATS led to significant 
morphological changes and inhibition of cell proliferation in rat HSCs.

Proteomics is an emerging field in medical science focusing on the library of transcripts specific to a given bio-system. Pharmacoproteomics is the application of proteomic technologies in drug development and assessment of drug administration (D'Alessandro and Zolla 2010; Yu 2011). Analyses of the transcriptome and the proteome of human HSCs have been reported with valuable data (Buchholz et al. 2005; Paulo et al. 2013) to promote our understanding of the physiology of HSCs. Our data implied that several cell cycle-associated or apoptosis-associated proteins in HSCs were induced by DATS treatment.

\section{Materials and methods}

\section{Reagents}

DATS was purchased from ChromaDex Company (USA). All chemical reagents for 2-DE were purchased from Amersham Biosciences (Uppsala, Sweden), and HPLC grade solvents were obtained from J.T. Baker (Phillipsburg, New Jersey, USA). Trypsin and dimethyl sulfoxide (DMSO) were purchased from Sigma (St. Lousis, Missouri, USA). The protein concentration was determined by the Bradford method using a 2D Quant kit (Amresco) according to the manufacturer's instructions. Proteins were initially separated using an Ettan IPGphor 3 Isoelectric Focusing System (GE Healthcare).

\section{Cell culture and DATS treatment}

Rat hepatic stellate cells (HSC-T6) were obtained from Cancer Institute and Hospital, Chinese Academy of Medical Sciences (Beijing, China). Cells were cultured in Dulbecco's modified Eagle's medium (Invitrogen, California, USA) containing 10\% fetal bovine serum, $100 \mathrm{U} / \mathrm{mL}$ penicillin, and $100 \mu \mathrm{g} / \mathrm{mL}$ streptomycin at $37^{\circ} \mathrm{C}$ in a humidified $5 \% \mathrm{CO}_{2}$ incubator. After reaching 60\% confluence, the cells were treated with $12 \mu \mathrm{g} / \mathrm{mL}$ or $24 \mu \mathrm{g} / \mathrm{mL}$ DATS for $6 \mathrm{~h}, 12 \mathrm{~h}$ and $24 \mathrm{~h}$, respectively. DATS was dissolved in $0.1 \%$ DMSO. Cells treated with DMSO alone were regarded as the control.

\section{MTT assay}

The effect of DATS on cell viability was measured by the MTT [3-(45dimethylthiozol-2-yl)-2, 5-diphenyltetrazolium bromide] assay (Li et al. 2013), which was based on the ability of live cells to convert thiazolyl blue to dark blue formazan. Exponentially growing HSCs were seeded into 96-well culture plates at $4 \times$ 
$10^{3}$ cells per well and treated with or without DATS for $6 \mathrm{~h}, 12 \mathrm{~h}$ and $24 \mathrm{~h}$, respectively. After treatment, MTT $(5 \mathrm{mg} / \mathrm{mL})$ was added into each well for continual incubation at $37^{\circ} \mathrm{C}$ for $4 \mathrm{~h}$ followed by DMSO into each well to dissolve the formazan product for $30 \mathrm{~min}$ at room temperature. A 96-well microplate reader (Rayto, USA) was used to measure the absorbance at $570 \mathrm{~nm}$ (A570). At least three independent experiments were carried out.

\section{BrdU assay}

HSCs were cultured as described above. Cells were seeded in 6-well culture plates at a density of $1 \times 10^{5}$ cells/well in a plating medium consisting of F10 medium supplemented with 10\% FCS and penicillin/streptomycin. After $48 \mathrm{~h}$, the culture medium was replaced with F10 medium containing 0.1\% FCS and $\operatorname{BrdU}(100 \mu \mathrm{M})$. After $24 \mathrm{~h}$ of serum starvation, DATS was added to the medium and the cultures were incubated at the indicated dose and time. The medium was aspirated and immediately fixed with anti-BrdU. The cells were washed in PBS and processed for immunofluorescence.

\section{Morphological study of apoptotic cells}

HSCs were collected and washed 3 times in PBS, and then incubated with the Hoechst 33342 (fluorescent DNA dye). The morphology of apoptosis was studied using fluorescence microscopy. Cells were treated with $24 \mu \mathrm{g} / \mathrm{mL}$ DATS for $12 \mathrm{~h}$ and conventionally fixed in $2.5 \%$ glutaraldehyde solution, dehydrated, penetrated, ultrathin sliced and electron-stained. Ultrastructural changes were observed with a transmission electron microscope (TEM).

\section{Cell cycle analysis by flow cytometry}

Flow cytometry was performed with annexin V/fluorescein isothiocyanate (FITC) Apoptosis Detection Kit (Bender, Austria) (Xiao et al. 2009) to determine the apoptosis of HSCs treated with $24 \mu \mathrm{g} / \mathrm{mL}$ DATS for $6 \mathrm{~h}, 12 \mathrm{~h}$ and $24 \mathrm{~h}$, respectively. After treatment with DATS or DMSO, the harvested cells were washed twice with precooled PBS and suspended in $250 \mathrm{uL}$ binding buffer to modulate the cell concentration at $1 \times 10^{6}$ cells $/ \mathrm{mL}$. Then, $100 \mu \mathrm{L}$ of the cell suspension was pipetted into a $5 \mathrm{~mL}$ test tube, with $5 \mu \mathrm{L}$ annexin V/FITC and $10 \mu \mathrm{L}$ PI added to it. After this mixture was incubated for $15 \mathrm{~min}$ at room temperature, $400 \mu \mathrm{L}$ PBS was added to the test tube. The rate of apoptotic cells was analyzed on FACSC alibur, and a cell isometric chart composed of four quadrants was acquired after analysis. The total number of apoptotic cells included earlier apoptotic cells and secondary apoptotic 
cells. Three independent experiments were performed, and the data was presented as mean \pm standard deviation (SD).

\section{Sample preparation for two-dimensional electrophoresis}

HSCs were washed three times with ice-cold PBS and lysed using lysis buffer containing $7 \mathrm{M}$ urea, 2\% 3-[(3-cholamidopropyl)-dimethylammonio]-1propanesulfonate (CHAPS), $2 \mathrm{M}$ thiourea (Amersham), $20 \mathrm{mM}$ Tris- $\mathrm{HCl}$ (pH 8.5, Amresco) and 1mM PMSF (freshly added before use, Amresco). Then, the sample was sonicated on ice and centrifuged at $12,000 \mathrm{~g}$ for $20 \mathrm{~min}$ at $4{ }^{\circ} \mathrm{C}$. The supernatant was transferred to a new centrifuge tube containing four times volume of acetone. The mixture was then precipitated overnight at $-20{ }^{\circ} \mathrm{C}$ and centrifuged under the same conditions. The precipitate was harvested and stored at $-80{ }^{\circ} \mathrm{C}$. The samples were processed in triplicate.

\section{Isoelectric focusing electrophoresis}

The isoelectric focusing electrophoresis was performed as previously described (Garcia-Hernandez et al. 2012). Briefly, $120 \mu \mathrm{g}$ proteins were solubilized directly in rehydration buffer, $1 \%$ DTT, $1 \%$ IPG-buffer and $0.002 \%$ bromophenol blue, and the total volume was $460 \mu \mathrm{L}$. Proteins were initially separated using an Ettan IPGphor 3 Isoelectric Focusing System (GE Healthcare). Different groups of HSC proteins were focused to their isoelectric points on a $24 \mathrm{~cm}(\mathrm{pH} \mathrm{4} \mathrm{7)} \mathrm{Immobiline} \mathrm{DryStrip} \mathrm{(GE}$ Healthcare) using the following parameters: $300 \mathrm{~V}$ for $30 \mathrm{~min}, 700 \mathrm{~V}$ for $30 \mathrm{~min}$, $1,500 \mathrm{~V}$ for $1.5 \mathrm{~h}, 9,000 \mathrm{~V}$ for $3 \mathrm{~h}$, and finally $9,000 \mathrm{~V}$ for $4 \mathrm{~h}$. After the isoelectric focusing, the immobilized $\mathrm{pH}$ gradient (IPG) strip was equilibrated for $15 \mathrm{~min}$ in equilibration buffer containing $2 \%$ sodium dodecyl sulfate, $50 \mathrm{mM}$ Tris- $\mathrm{HCl}(\mathrm{pH} 8.8)$, $6 \mathrm{M}$ urea, 30\% (v/v) glycerol, $0.002 \%$ bromophenol blue and $100 \mathrm{mM}$ dithiothreitol (freshly added before use, Amresco), followed by a second wash for 15 min with equilibration buffer containing $250 \mathrm{mM}$ iodoacetamide (freshly added before use, Amersham).

\section{Sodium dodecyl sulfate polyacrylamide gel electrophoresis}

After equilibration, the immobilized $\mathrm{pH}$ gradient strips were loaded onto $12.5 \%$ $(\mathrm{w} / \mathrm{v})$ homogeneous acrylamide gels and sealed with $0.8 \%(\mathrm{w} / \mathrm{v})$ agarose. Proteins were separated by running the gels at $2 \mathrm{~W} / \mathrm{gel}$ for $45 \mathrm{~min}$ and then at $17 \mathrm{~W} / \mathrm{gel}$ at $10{ }^{\circ} \mathrm{C}$ until the bromochlorophenol blue dye reached the end of gels. The protein spots were visualized by silver staining and rinsed with deionized water.

\section{Gel analysis}


The gels were scanned at a resolution of 200 dots/in (dpi) using a scanner (Powerlook1100, UMAX) and analyzed by ImageMaster ${ }^{\mathrm{TM}}$ 2D Platinum 5.0 software (GE Healthcare) for spot detection, spot matching and quantitative intensity analysis. Relative quantitative analysis of each spot between the control group and DATS treated group on the triplicate gels was performed using Student's t-test. The differentially expressed protein spots were manually excised from the silver stained gels and loaded into a 96-well microplate. The gel fragments were washed twice with MilliQ water, destained with $50 \%$ methanol at $37{ }^{\circ} \mathrm{C}$ for $30 \mathrm{~min}$, and dehydrated in $100 \mu \mathrm{L}$ of acetonitrile (ACN) at room temperature for $20 \mathrm{~min}$. Next, the samples were swollen in $50 \mu \mathrm{L}$ of $100 \mathrm{mM} \mathrm{NH} \mathrm{NHCO}_{3}$, dehydrated for the second time and incubated in $1 \mu \mathrm{g} / 50 \mu \mathrm{L}$ trypsin (Promega) at $4{ }^{\circ} \mathrm{C}$ for $30 \mathrm{~min}$. Then, the samples were supplemented with coverage solution $\left(10 \% \mathrm{ACN}, 50 \mathrm{mM} \mathrm{NH} \mathrm{HCO}_{3}\right.$, Milli-Q water) and incubated at $37^{\circ} \mathrm{C}$ for $16 \mathrm{~h}$.

After suction of the coverage solution, the peptide mixtures were extracted using $2.5 \%$ trifluoroacetic (TFA)/90\% $\mathrm{ACN}$ at room temperature for $30 \mathrm{~min}$ and finally vacuum-dried. After vacuum drying, the material was dissolved in $1.5 \mu \mathrm{L}$ solution containing Milli-Q water, $50 \%$ ACN and $0.1 \%$ TFA. Then, $0.8 \mu \mathrm{L}$ of the mixture was loaded onto a target plate with $0.5 \mu \mathrm{L}$ HCCA $(5 \mathrm{mg} / \mathrm{mL}$ a-cyano-4-hydroxycinnamic acid) matrix, dried at room temperature and analyzed using an ABI 4800 MALDITOF/TOF proteomics analyzer mass spectrometer (Applied Biosystems, USA). The UV laser was operated at a $200-\mathrm{Hz}$ repetition rate with a wavelength of $355 \mathrm{~nm}$ and an accelerated voltage of $20 \mathrm{kV}$.

\section{Database search}

The experimental MS data were matched to a corresponding virtual peptide mass database derived from GPS Explorer ${ }^{\mathrm{TM}}$ v3.6, the Mascot, and the International Protein Index (IPI) mouse protein database. All acquired spectra of samples were processed using the Mascot software (http://www.matrixscience.com). The search parameters were as follows: database: IPI mouse; enzyme: trypsin; fixed modifications: carbamidomethylation; and variable modifications: oxidation $(\mathrm{M})$. The function, gene name, and Gene Ontology (GO) category of each protein were determined using the Mascot v2.1 software protein database search engine and the IPI mouse protein database. We selected a reference gel against which each of the other gel images was matched. Three gels per sample underwent automatic spot detection and manual editing before automatic spot matching both within and between groups. Manual 
matching was conducted as needed. Base-pair normalization was carried out on all the gels before examination of spot volume data. Gels were normalized in accordance with ImageMaster software protocols using base-pair normalization.

\section{Statistical analysis}

Values were expressed as mean \pm SD and analyzed by one-way analysis of variance (ANOVA) and Fisher's least significant difference test to determine significant differences among group means $(P<0.05)$.

\section{Results}

\section{DATS inhibited cell viability in HSCs}

In this study, the effect of DATS on the viability and proliferation of HSCs was assessed using the MTT assay and BrdU assay, respectively. The anti-proliferative effect of DATS on HSCs was assessed by exposing them to different concentrations of DATS $(12 \mu \mathrm{g} / \mathrm{mL}$ or $24 \mu \mathrm{g} / \mathrm{mL})$ for $6 \mathrm{~h}, 12 \mathrm{~h}$ and $24 \mathrm{~h}$, respectively. Exposure of HSCs to DATS resulted in a decrease in cell viability and proliferation in a timedependent manner (Fig.1A and 1B). A significant inhibition of cell growth was observed after $24 \mathrm{~h}$ of incubation with DATS at different concentrations. When HSCs were treated with $24 \mu \mathrm{g} / \mathrm{mL}$ DATS for $24 \mathrm{~h}$, the cell viability measured by MTT assay was decreased to $55.7 \pm 3.8 \%$ (Fig. 1A) and the cell proliferation measured by BrdU assay was decreased to $28.5 \pm 0.8 \%$ (Fig. 1B).

\section{Effects of DATS on HSC morphology and cell cycle}

To explore the effect of DATS on HSC morphological changes and apoptosis, the membrane permeable DNA-binding dye Hoechst 33342 was used to stain the nuclei of HSCs. DATS caused apoptotic cell death characterized by nuclear condensation and fragmentation as well as bright staining visible under the fluorescent microscope (Fig. 2). We observed that DATS induced apoptosis in both high and low doses. The percentage of apoptotic cells treated with $24 \mu \mathrm{g} / \mathrm{mL}$ DATS was significantly higher than that in $12 \mu \mathrm{g} / \mathrm{mL}$ DATS-treated cells. The shape of the cells changed from stellate or shuttle to spherical, and the intercellular space was increased. After the $12 \mathrm{~h}$ incubation, the cells began to detach from the flask. Using the transmission electron microscope (TEM), we observed decreased volume, condensed chromatin and decreased nucleo-cytoplasmic ratio of apoptotic cells. Some cells showed typical apoptotic changes including pyknosis and margination of the nuclear chromatin. However, TEM showed nuclear fragmentation, annular or crescent body, cytoplasmic 
vacuoles and swollen mitochondria as well as karyolysis of cells resulting in specific apoptotic bodies (Fig. 3). In addition, HSCs were incubated with $24 \mu \mathrm{g} / \mathrm{mL}$ DATS for $6 \mathrm{~h}, 12 \mathrm{~h}$ and $24 \mathrm{~h}$, and analyzed using annexin V-FITC/PI staining with flow cytometry (Fig. 4). The results showed that DATS induced apoptosis of HSCs in a time-dependent manner. Compared with the vehicle control (DMSO), DATS significantly induced apoptosis of HSCs after $12 \mathrm{~h}$ and $24 \mathrm{~h}$ treatment, regardless of the $6 \mathrm{~h}$ treatment (Fig. 4A). Quantitatively, DATS treatment for $12 \mathrm{~h}$ and $24 \mathrm{~h}$ resulted in a statistically significant increase of apoptosis rates, compared with the untreated control group (12 h treatment: $13.97 \% \pm 0.37 \%$ vs. $8.83 \% \pm 1.64 \%$ and $24 \mathrm{~h}$ treatment: $21.27 \% \pm 0.93 \%$ vs. $9.44 \% \pm 0.77 \%$, respectively) (Fig. 4B).

Furthermore, we also detected the effects of DATS treatment on cell cycle regulation in HSCs (Fig. 5). Treatment with $24 \mu \mathrm{g} / \mathrm{mL}$ DATS resulted in statistically significant enrichment of G2/M fraction and a decrease of $\mathrm{S}$ fraction in HSCs (Fig. 5A). The G2/M phase cell cycle arrest was presented as early as $12 \mathrm{~h}$ after DATS treatment and persisted until $24 \mathrm{~h}$ post-exposure. The percentage of G2/M fraction in HSCs was higher by about 1.2 to 1.6 folds after treatment with $24 \mu \mathrm{g} / \mathrm{mL}$ DATS for $12 \mathrm{~h}$ and 24h, respectively, compared with the DMSO-treated controls (Fig. 5B).

\section{Two-dimensional electrophoresis (2-DE) pattern}

We used 2-DE in conjunction with quantitative image analysis and peptide sequencing by mass spectrometry to investigate the changes of protein expression in HSCs treated with or without DATS. According to the 2-DE imaging, the proteins in HSCs treated with or without DATS were electrophoretically similar in molecular mass and pI (Fig. 6). The spots were biased toward the specific $\mathrm{pH}$ regions on the IPG strips, whereas they were evenly distributed over the range of molecular mass from 10 to $170 \mathrm{kDa}$ on $12 \%$ SDS-polyacrylamide gel. The total spots were $1893 \pm 107(n=3)$ and $1734 \pm 97(n=3)$ in the control and DATS-treated groups, respectively. After normalization, the spot densities were determined based on total quantity in the analysis set. Protein spots that showed significant and consistent increase or decrease in density (paired $t$-test, $P<0.05$ ) were selected and defined as up- or down-regulated spots. A total of 21 spots were defined as DATS-sensitive in HSCs, including 9 downregulated spots and 12 up-regulated spots.

\section{Identification of differentially expressed proteins}

The spots from the 2-DE gel were subjected to trypsin digestion and MALDI-TOFTOF MS analysis. On the basis of mass spectrometry data, 21 spots matched with the 
proteins, and 21 spots were ascertained as unique proteins including 9 down-regulated and 12 up-regulated proteins. To identify the differentially expressed proteins in DATS-treated HSCs in 2-DE gels, a total of 21 proteins spots with a threshold greater than 1.5-fold were excised from these 2-DE gels and subjected to in-gel trypsin digestion and subsequent MALDI-TOF/TOF identification. Table 1 provides a list of 21 differentially expressed spots, which were successfully identified.

According to the annotations from the UniProt Knowledgebase (SwissProt/TrEMBL) and Gene Ontology Database, the percentage of up-regulated and down-regulated protein spots by DATS was 42.9\% and 57.1\%, respectively. The 12 up-regulated spots corresponded to the following 10 proteins: heterogeneous nuclear ribonucleoprotein $\mathrm{K}$ (hnRNP K), elongation factor 1-gamma (EF-1 $\gamma$ ), elongation factor $\mathrm{Tu}$, isocitrate dehydrogenase $3\left(\mathrm{NAD}^{+}\right)$alpha, L-lactate dehydrogenase $\mathrm{B}$ chain, nucleophosmin (NPM), elongation factor 1-delta (EF-1 $\delta$ ), annexin A3, annexin A4 and isoform CRA_b. Meanwhile, 9 down-regulated spots corresponded to the following 8 proteins: Grp75, dnaK gene product, heterogeneous nuclear ribonucleoprotein $\mathrm{K}$, T-complex protein 1 (TCP-1) subunit epsilon, mitochondrial aldehyde dehydrogenase (ALDH), elongation factor Tu, isoform CRA_c and GD24601. Among the 21 differentially expressed spots, several different spots were identified as the products of the same gene, including heterogeneous nuclear ribonucleoprotein $\mathrm{K}$ and nucleophosmin. Unexpectedly, two spots (including one upregulated and the other down-regulated) were identified as elongation factor $\mathrm{Tu}$. Another four spots (including two up-regulated and the other two down-regulated) were identified as heterogeneous nuclear ribonucleoprotein $\mathrm{K}$.

\section{Discussion}

In this study, we treated HSCs with $12 \mu \mathrm{g} / \mathrm{ml}$ DATS and $24 \mu \mathrm{g} / \mathrm{ml}$ DATS for $6 \mathrm{~h}, 12$ $\mathrm{h}$ and $24 \mathrm{~h}$, respectively. We observed clear apoptosis following $12 \mathrm{~h}$ treatment with DATS $(24 \mu \mathrm{g} / \mathrm{mL})$. Significant differences in decreased viability of HSCs and induction of apoptosis were observed at higher concentration when compared with the lower concentration and the control group. The results show that the percentage of apoptotic cells was time-dependent on DATS treatment suggesting that DATS induced apoptosis of HSC in vitro. Accordingly, obvious morphological changes of apoptosis were observed using TEM, and cell cycle changes were analyzed using flow cytometry. These results demonstrate that DATS manifested anti-proliferation and 
apoptosis-inducing activities against HSCs. The results show for the first time that DATS induced apoptosis of HSCs. The findings provide an insight into the potential anti-fibrotic mechanism of DATS. Accordingly, an in vivo study had showed that garlicin at $11 \mathrm{mg} / \mathrm{kg}$ exhibited protective effect on hepatic fibrosis induced by dimethylnitrosamine in rat. Based on pharmacokinetics, the in vivo dosage of 11 $\mathrm{mg} / \mathrm{kg}$ was basically equivalent to the in vitro dosage of $24 \mu \mathrm{g} / \mathrm{mL}$, when liver firstpass effect is ignored in rat. In addition, we also showed that 21 spots were defined as proteins with 18 unique ones, including 14 directly or indirectly related to apoptosis.

Annexins were among the most significantly up-regulated proteins by DATS. Annexins are a family of structurally related, $\mathrm{Ca}^{2+}$-sensitive proteins that bind to negatively charged phospholipids and establish specific interactions with other lipids and lipid microdomains. Annexins participate in a variety of intracellular processes, ranging from the regulation of membrane dynamics to cell migration, proliferation, and apoptosis (Monastyrskaya et al. 2009). Annexin A3 is a special member of Annexin family. Yan et al. showed that increased Annexin A3 expression contributed to platinum resistance in ovarian cancer. Furthermore, Annexin A3 inhibited apoptosis induced by cisplatin in human epithelial ovarian cancer cells (Yan et al. 2010). In contrast, we found that Annexin A3 was significantly higher in DATStreated group than that in control groups. Therefore, we hypothesized that Annexin A3 may participate in the apoptosis of HSCs and play a role of pro-apoptotic effect. Our data indicate that increased expression of Annexin A3 may be a specific mechanism of apoptosis induction in HSCs.

In addition, we found that DATS increased the expression of elongation factor 1delta. Elongation factor-1 (EF-1) delta is a subunit of EF-1, which is a protein complex that participates in the elongation step of mRNA translation and has recently been considered to be correlated with oncogenic transformation (Lei et al. 2010; Ogawa et al. 2004). However, no study has been conducted regarding the significance of EF-1 delta mRNA expression in HSCs. This observation appears to indicate that changes in translational processes occur in early phase of apoptosis of HSCs, which might eventually influence the expression levels of different set of proteins.

Nucleophosmin (NPM) is a ubiquitously expressed chaperone protein that shuttles rapidly between the nucleus and cytoplasm, while it predominantly resides in the nucleolus. It plays key roles in ribosome biogenesis, centrosome duplication, genomic stability, cell cycle progression and apoptosis (Rau and Brown 2009). Furthermore, it 
is a multifunctional protein frequently overexpressed in actively proliferating cells ( $\mathrm{Li}$ et al. 2006). Although no evidence indicates that NPM is required for activation and genomic stability of hepatic stellate cells, we observed that DATS increased the protein expression of NPM. We suspect that NPM is another regulatory molecule that plays a role in DATS-induced HSCs proliferation inhibition and apoptosis.

Glucose-regulated protein 75 (Grp75) is one of the most significantly downregulated proteins by DATS. Grp75 belongs to the family of heat shock protein 70. It acts a part in the control of cell proliferation and cellular aging, as well as a chaperone. DnaK (Hsp70) chaperone plays a key role in cellular physiology. The folding of most newly synthesized proteins in the cell requires the interaction of a variety of protein cofactors known as molecular chaperones. As a molecular chaperone, Grp75 plays an important role in the suppression of apoptosis (Yang et al. 2011). This study showed that DATS down-regulated the expression of grp75 in HSCs, resulting in the abrogation of cell proliferation. The universally conserved molecular chaperone machines maintain cellular protein homeostasis by acting at almost every stage in the life of proteins (Hartl 2011).

Additionally, aldehyde dehydrogenases (ALDH) are a group of enzymes that catalyze the oxidation (dehydrogenation) of aldehydes (Marchitti et al. 2008). ALDH2 has been proved to be involved in oxidative stress-induced cell apoptosis (Hu et al. 2011), while little is known in HSCs. In the present study, we found that ALDH protein expression was down-regulated by DATS in HSCs, suggesting that ALDH might play a vital role in protecting DATS-induced apoptosis in HSCs.

Molecular chaperones play an important role in the folding of many proteins and the CCT complex is a member of the two major chaperone systems that promote the folding and assembly of a wider range of cytosolic substrates. T-complex protein 1 subunit epsilon is one of subunits of Chaperonin-containing TCP-1 (CCT), a heterooligomeric ring complex composed of eight subunits $(\alpha, \beta, \gamma, \delta, \varepsilon, \zeta, \eta$ and $\theta)$ (Bouhouche et al. 2006; Llorca et al. 2001). CCT is necessary for the folding of actin and tubulin in the cytosol. The relationship between T-complex protein 1 subunit epsilon and cell apoptosis still remains unclear.

Interestingly, we observed that two heterogeneous nuclear ribonucleoprotein $\mathrm{K}$ (hnRNP K) protein spots presented an increase, whereas another two hnRNP K protein spots presented a decrease. The hnRNP $\mathrm{K}$ is a highly conserved RNA-binding protein that was initially identified as part of the hnRNP complex (Dreyfuss et al. 
1993). The hnRNP K contains multiple modules that simultaneously engage proteins and nucleic acids and appear to facilitate molecular interactions (Bomsztyk et al. 1997; Gao et al. 2009; Matunis et al. 1992). The hnRNP K has been implicated in apoptosis and mediates several signal transduction pathway, but its precise role in apoptosis has not been clearly defined (Gao et al. 2009; White et al. 2010). A recent study reported that hnRNP K plays an anti-apoptotic role in HCC cells, independent of p53 status, via maintenance of high levels of endogenous caspase inhibitors (Xiao et al. 2013). Our results indicated that different isoforms or modification of hnRNP K may play different roles during DATS treatment of HSCs. Nevertheless, this study suggested that hnRNP K may play a complicated role in HSCs, and hnRNP K might be as a possible therapeutic marker for hepatic fibrosis. Similarly, there was one protein spot of elongation factor thermo unstable (EF-Tu) presenting an increase and another EF-Tu protein spot presenting a decrease. EF-Tu is one of the prokaryotic elongation factors and a GTP-binding protein that delivers aminoacyl-tRNA to the A site of the ribosome during protein synthesis (Daviter et al. 2003). This result indicated that the up-regulated EF-Tu may not be specific to DATS-treated HSCs. However, further studies are warranted to investigate whether EF-Tu plays a role in the apoptosis of HSCs.

In summary, our study suggested that DATS induced apoptosis of HSCs. Furthermore, we detected significant expression changes in proteins related to apoptosis of HSCs using comparative 2DE-analysis. To the best of our knowledge, some of these proteins, which are related to the pathophysiological mechanisms of liver fibrosis, have never been described in this disease. Several differentially expressed proteins were identified by MALDI-TOF-TOF and some of them may be related to apoptosis, supporting the hypothesis that DATS is an inducer of apoptosis in HSCs. The proteomic data provide clues for the investigation of potential molecular markers for DATS-induced apoptosis in HSCs. These findings also provide an insight into the molecular mechanism of anti-fibrotic function of DATS. Although the exact molecular mechanisms underlying significant protein changes in the HSCs after DATS treatment should be further studied, our results provide valuable insight into the development of potential treatment strategies for liver fibrosis using DATS.

\section{Acknowledgements}

We thank Dr. Liguo Wang and Dr. Ningling Kang at Gastroenterology Research 
Unit, Mayo Clinic for valuable discussions. This work was supported by the National Natural Science Foundation of China (grant No. 81060274, 81360507), the Technology Research and Development Project of Shihezi University (grant No. RCZX201025) and Scholarship for Preferred Science and Technology Activities for Returned Students by Ministry of Human Resources and Social Security of China. The experiments comply with the appropriate national legislations.

\section{References}

Bataller, R., and Brenner, D.A. 2005. Liver fibrosis. J. Clin. Invest. 115(2): 209-218. doi: 10.1172/JCI24282.

Bomsztyk, K., Van Seuningen, I., Suzuki, H., Denisenko, O., and Ostrowski, J. 1997. Diverse molecular interactions of the hnRNP K protein. FEBS Lett. 403(2): 113-115.

Borek, C. 2001. Antioxidant health effects of aged garlic extract. J. Nutr. 131(3s): 1010S-1015S.

Bouhouche, A., Benomar, A., Bouslam, N., Chkili, T., and Yahyaoui, M. 2006. Mutation in the epsilon subunit of the cytosolic chaperonin-containing t-complex peptide-1 (Cct5) gene causes autosomal recessive mutilating sensory neuropathy with spastic paraplegia. J. Med. Genet. 43(5): 441-443. doi: 10.1136/jmg.2005.039230.

Buchholz, M., Kestler, H.A., Holzmann, K., Ellenrieder, V., Schneiderhan, W., Siech, M., Adler, G., Bachem, M.G., and Gress, T.M. 2005. Transcriptome analysis of human hepatic and pancreatic stellate cells: organ-specific variations of a common transcriptional phenotype. J. Mol. Med. (Berl.) 83(10): 795-805. doi: 10.1007/s00109-005-0680-2.

Chandra-Kuntal, K., Lee, J., and Singh, S.V. 2013. Critical role for reactive oxygen species in apoptosis induction and cell migration inhibition by diallyl trisulfide, a cancer chemopreventive component of garlic. Breast Cancer Res. Treat. 138(1): 69-79. doi: 10.1007/s10549-013-2440-2.

Chen, H., Zhu, W., Feng, J., and Li, S. 2012. Protective effect of diallyl trisulfide on liver in rats with sepsis and the mechanism. J. Huazhong Univ. Sci. Technolog. Med. Sci. 32(5): 657-662. doi: 10.1007/s11596-012-1013-7.

Curry, M.P. 2013. HIV and hepatitis C virus: special concerns for patients with cirrhosis. J. Infect. Dis. 207 Suppl 1: S40-44. doi: 10.1093/infdis/jis763.

D'Alessandro, A., and Zolla, L. 2010. Pharmacoproteomics: a chess game on a protein field. Drug Discov. Today, 15(23-24): 1015-1023. doi: 10.1016/j.drudis.2010.10.002.

D'Argenio, G., Mazzone, G., Ribecco, M.T., Lembo, V., Vitaglione, P., Guarino, M., Morisco, F., Napolitano, M., Fogliano, V., and Caporaso, N. 2013. Garlic extract attenuating rat liver fibrosis by inhibiting TGF-beta1. Clin. Nutr. 32(2): 252-258. doi: 10.1016/j.clnu.2012.07.001.

Daviter, T., Wieden, H.J., and Rodnina, M.V. 2003. Essential role of histidine 84 in elongation factor Tu for the chemical step of GTP hydrolysis on the ribosome. J. Mol. Biol. 332(3): 689-699.

Dreyfuss, G., Matunis, M.J., Pinol-Roma, S., and Burd, C.G. 1993. hnRNP proteins and the biogenesis of mRNA. Annu Rev Biochem 62: 289-321. doi: 10.1146/annurev.bi.62.070193.001445.

Fallowfield, J.A. 2011. Therapeutic targets in liver fibrosis. Am. J. Physiol. 300(5): G709-715. doi: 10.1152/ajpgi.00451.2010.

Gao, F.H., Wu, Y.L., Zhao, M., Liu, C.X., Wang, L.S., and Chen, G.Q. 2009. Protein kinase C-delta mediates down-regulation of heterogeneous nuclear ribonucleoprotein $\mathrm{K}$ protein: involvement in 
apoptosis induction. Exp. Cell Res. 315(19): 3250-3258. doi: 10.1016/j.yexcr.2009.09.005.

Garcia-Hernandez, V., Sanchez-Bernal, C., Sarmiento, N., Viana, R.A., Ferreira, L., Perez, N., Calvo, J.J., and Sanchez-Yague, J. 2012. Proteomic analysis of the soluble and the lysosomal+mitochondrial fractions from rat pancreas: Implications for cerulein-induced acute pancreatitis. Biochim. Biophys. Acta, 1824(9): 1058-1067. doi: 10.1016/j.bbapap.2012.06.003.

Hartl, F.U. 2011. Chaperone-assisted protein folding: the path to discovery from a personal perspective. Nat. Med. 17(10): 1206-1210. doi: 10.1038/nm.2467.

Hu, X.Y., Fang, Q., Wang, J.S., Xie, J.Q., Chai, B.S., Li, F.Q., Cui, X., and Yang, Y. 2011. Overexpression of aldehyde dehydrogenase-2 protects against $\mathrm{H}(2) \mathrm{O}(2)$-induced oxidative damage and apoptosis in peripheral blood mononuclear cells. Acta Pharmacol. Sin. 32(2): 245-252. doi: 10.1038/aps.2010.203.

Lei, Y.X., Wang, M., Wei, L., Lu, X., and Lin, H.Z. 2010. Alternative expression and sequence of human elongation factor-1 delta during malignant transformation of human bronchial epithelial cells induced by cadmium chloride. Biomed. Environ. Sci. 23(2): 151-157.

Li, J., Sejas, D.P., Rani, R., Koretsky, T., Bagby, G.C., and Pang, Q. 2006. Nucleophosmin regulates cell cycle progression and stress response in hematopoietic stem/progenitor cells. J. Biol. Chem. 281(24): 16536-16545. doi: 10.1074/jbc.M601386200.

Li, Y., Zhang, J., Zhang, L., Si, M., Yin, H., and Li, J. 2013. Diallyl trisulfide inhibits proliferation, invasion and angiogenesis of osteosarcoma cells by switching on suppressor microRNAs and inactivating of Notch-1 signaling. Carcinogenesis, 34(7): 1601-1610. doi: 10.1093/carcin/bgt065.

Llorca, O., Martin-Benito, J., Gomez-Puertas, P., Ritco-Vonsovici, M., Willison, K.R., Carrascosa, J.L., and Valpuesta, J.M. 2001. Analysis of the interaction between the eukaryotic chaperonin CCT and its substrates actin and tubulin. J. Struct. Biol. 135(2): 205-218. doi: 10.1006/jsbi.2001.4359.

Marchitti, S.A., Brocker, C., Stagos, D., and Vasiliou, V. 2008. Non-P450 aldehyde oxidizing enzymes: the aldehyde dehydrogenase superfamily. Expert Opin. Drug Metab. Toxicol. 4(6): 697-720. doi: 10.1517/17425255.4.6.697.

Matunis, M.J., Michael, W.M., and Dreyfuss, G. 1992. Characterization and primary structure of the poly(C)-binding heterogeneous nuclear ribonucleoprotein complex K protein. Mol. Cell. Biol 12(1): 164-171.

Monastyrskaya, K., Babiychuk, E.B., and Draeger, A. 2009. The annexins: spatial and temporal coordination of signaling events during cellular stress. Cell. Mol. Life Sci. 66(16): 2623-2642. doi: 10.1007/s00018-009-0027-1.

Morgan, R.L., Baack, B., Smith, B.D., Yartel, A., Pitasi, M., and Falck-Ytter, Y. 2013. Eradication of hepatitis $\mathrm{C}$ virus infection and the development of hepatocellular carcinoma: a meta-analysis of observational studies. Ann. Intern. Med. 158(5 Pt 1): 329-337. doi: 10.7326/0003-4819-158-5201303050-00005.

Ogawa, K., Utsunomiya, T., Mimori, K., Tanaka, Y., Tanaka, F., Inoue, H., Murayama, S., and Mori, M. 2004. Clinical significance of elongation factor-1 delta mRNA expression in oesophageal carcinoma. Br. J. Cancer, 91(2): 282-286. doi: 10.1038/sj.bjc.6601941.

Paulo, J.A., Kadiyala, V., Banks, P.A., Conwell, D.L., and Steen, H. 2013. Mass spectrometry-based quantitative proteomic profiling of human pancreatic and hepatic stellate cell lines. Genomics Proteomics Bioinformatics, 11(2): 105-113. doi: 10.1016/j.gpb.2013.01.009.

Rau, R., and Brown, P. 2009. Nucleophosmin (NPM1) mutations in adult and childhood acute myeloid leukaemia: towards definition of a new leukaemia entity. Hematol. Oncol. 27(4): 171-181. doi: 
10.1002/hon.904.

Senoo, H. 2004. Structure and function of hepatic stellate cells. Med. Electron Microsc. 37(1): 3-15. doi: 10.1007/s00795-003-0230-3.

Tacke, F., and Weiskirchen, R. 2012. Update on hepatic stellate cells: pathogenic role in liver fibrosis and novel isolation techniques. Expert Rev. Gastroenterol. Hepatol. 6(1): 67-80. doi: 10.1586/egh.11.92.

Wang, Y.B., Qin, J., Zheng, X.Y., Bai, Y., Yang, K., and Xie, L.P. 2010. Diallyl trisulfide induces Bcl-2 and caspase-3-dependent apoptosis via downregulation of Akt phosphorylation in human T24 bladder cancer cells. Phytomedicine, 17(5): 363-368. doi: 10.1016/j.phymed.2009.07.019.

White, M.C., Gao, R., Xu, W., Mandal, S.M., Lim, J.G., Hazra, T.K., Wakamiya, M., Edwards, S.F., Raskin, S., Teive, H.A., Zoghbi, H.Y., Sarkar, P.S., and Ashizawa, T. 2010. Inactivation of hnRNP K by expanded intronic AUUCU repeat induces apoptosis via translocation of PKCdelta to mitochondria in spinocerebellar ataxia 10. PLoS Genet. 6(6): e1000984. doi: 10.1371/journal.pgen.1000984.

Xiao, D., Zeng, Y., and Singh, S.V. 2009. Diallyl trisulfide-induced apoptosis in human cancer cells is linked to checkpoint kinase 1-mediated mitotic arrest. Mol. Carcinog. 48(11): 1018-1029. doi: 10.1002/mc.20553.

Xiao, Z., Ko, H.L., Goh, E.H., Wang, B., and Ren, E.C. 2013. hnRNP K suppresses apoptosis independent of p53 status by maintaining high levels of endogenous caspase inhibitors. Carcinogenesis, 34(7): 1458-1467. doi: 10.1093/carcin/bgt085.

Yan, X., Yin, J., Yao, H., Mao, N., Yang, Y., and Pan, L. 2010. Increased expression of annexin A3 is a mechanism of platinum resistance in ovarian cancer. Cancer Res. 70(4): 1616-1624. doi: 10.1158/0008-5472.CAN-09-3215.

Yang, L., Guo, W., Zhang, Q., Li, H., Liu, X., Yang, Y., Zuo, J., and Liu, W. 2011. Crosstalk between Raf/MEK/ERK and PI3K/AKT in suppression of Bax conformational change by Grp75 under glucose deprivation conditions. J. Mol. Biol. 414(5): 654-666. doi: 10.1016/j.jmb.2011.09.009.

Yin, C., Evason, K.J., Asahina, K., and Stainier, D.Y. 2013. Hepatic stellate cells in liver development, regeneration, and cancer. J. Clin. Invest. 123(5): 1902-1910. doi: 10.1172/JCI66369.

Yu, L.R. 2011. Pharmacoproteomics and toxicoproteomics: the field of dreams. J. Proteomics, 74(12): 2549-2553. doi: 10.1016/j.jprot.2011.10.001.

Zeng, T., Zhang, C.L., Zhu, Z.P., Yu, L.H., Zhao, X.L., and Xie, K.Q. 2008. Diallyl trisulfide (DATS) effectively attenuated oxidative stress-mediated liver injury and hepatic mitochondrial dysfunction in acute ethanol-exposed mice. Toxicology, 252(1-3): 86-91. doi: 10.1016/j.tox.2008.07.062.

Zhang, Z.M., Yang, X.Y., Deng, S.H., Xu, W., and Gao, H.Q. 2007. Anti-tumor effects of polybutylcyanoacrylate nanoparticles of diallyl trisulfide on orthotopic transplantation tumor model of hepatocellular carcinoma in BALB/c nude mice. Chin. Med. J. (Engl.) 120(15): 1336-1342.

Zhu, X., Zhang, F., Zhou, L., Kong, D., Chen, L., Lu, Y., and Zheng, S. 2014. Diallyl trisulfide attenuates carbon tetrachloride-caused liver injury and fibrogenesis and reduces hepatic oxidative stress in rats. Naunyn Schmiedebergs Arch. Pharmacol. 387(5): 445-455. doi: 10.1007/s00210-0140959-3. 
Table 1. Differentially expressed proteins in HSCs after $12 \mathrm{~h}$ treatment with $24 \mu \mathrm{g} / \mathrm{mL}$ DTAS.

\begin{tabular}{|c|c|c|c|c|c|c|c|c|}
\hline $\begin{array}{l}\text { Spot } \\
\text { no. }^{a}\end{array}$ & Acc. no ${ }^{b}$ & $\begin{array}{l}\text { No.of } \\
\text { matched } \\
\text { peptides }\end{array}$ & $\begin{array}{l}\text { fold- } \\
\text { change }\end{array}$ & Protein name & $\begin{array}{l}\text { Experimental } \\
\mathrm{MW}^{\mathrm{d}}(\mathrm{kDa}) / \mathrm{pI}\end{array}$ & $\begin{array}{l}\text { Theoretical } \\
\text { MW } \\
(\mathrm{Da}) / \mathrm{pI}\end{array}$ & Cell localization & Function \\
\hline A1 & gi|1000439 & 10 & 1.75 & grp75 [Rattus sp.] & $71037 / 5.48$ & $73984 / 5.87$ & Mitochondrion & $\begin{array}{l}\text { Implicated in the control of cell } \\
\text { proliferation and cellular aging. } \\
\text { May also act as a chaperone }\end{array}$ \\
\hline A3 & gi|304373393 & 9 & 1.87 & $\begin{array}{l}\text { dnaK gene product } \\
\text { [Mycoplasma hyorhinis HUB-1] }\end{array}$ & $61729 / 5.01$ & $65004 / 5.04$ & $\begin{array}{l}\text { Cell inner } \\
\text { membrane } \\
\text { Cell membrane } \\
\text { Cytoplasm } \\
\text { Membrane }\end{array}$ & $\begin{array}{l}\text { Plays an essential role in the } \\
\text { initiation of phage lambda } \\
\text { DNA replication. DnaK is also } \\
\text { involved in chromosomal DNA } \\
\text { replication. Also participates } \\
\text { actively in the response to } \\
\text { hyperosmotic shock }\end{array}$ \\
\hline A4 & gi|149039794 & 2 & 1.63 & $\begin{array}{l}\text { heterogeneous } \\
\text { ribonucleoprotein } \mathrm{K}, \text { isoform } \\
\text { CRA_b [Rattus norvegicus] }\end{array}$ & $59171 / 5.47$ & $43059 / 5.43$ & $\begin{array}{l}\text { Cytoplasm/Nucleus/ } \\
\text { Nucleoplasm }\end{array}$ & $\begin{array}{l}\text { One of the major pre-mRNA- } \\
\text { binding proteins. Binds } \\
\text { tenaciously to poly }(\mathrm{C}) \\
\text { sequences }\end{array}$ \\
\hline A5 & gi|14165437 & 7 & 1.56 & $\begin{array}{l}\text { heterogeneous } \\
\text { ribonucleoprotein } \mathrm{K} \text { isoform a } \\
\text { [Homo sapiens] }\end{array}$ & $59285 / 5.39$ & $51281 / 5.19$ & $\begin{array}{l}\text { Cytoplasm/Nucleus/ } \\
\text { Nucleoplasm }\end{array}$ & $\begin{array}{l}\text { One of the major pre-mRNA- } \\
\text { binding proteins. Binds } \\
\text { tenaciously to poly }(\mathrm{C}) \\
\text { sequences. Likely to play a role } \\
\text { in the nuclear metabolism of } \\
\text { hnRNAs }\end{array}$ \\
\hline A6 & gi|51890219 & 5 & 1.67 & $\begin{array}{l}\text { T-complex protein } 1 \text { subunit } \\
\text { epsilon [Rattus norvegicus] }\end{array}$ & $52904 / 5.52$ & $59955 / 5.51$ & $\begin{array}{l}\text { Cytoplasm } \\
\text { Cytoskeleton }\end{array}$ & $\begin{array}{l}\text { Molecular chaperone; assists } \\
\text { the folding of proteins upon } \\
\text { ATP hydrolysis }\end{array}$ \\
\hline A7 & gi|25990263 & 2 & 2.66 & $\begin{array}{l}\text { mitochondrial } \\
\text { dehydrogenase } \\
\text { norvegicus }]\end{array}$ & $49265 / 5.93$ & $53809 / 5.70$ & Mitochondrion & $\begin{array}{l}\text { Catalytic activity } \\
\text { formyltetrahydrofolate } \\
\mathrm{NADP}^{+}+ \\
\text {tetrahydrofolate }+\mathrm{H}_{2} \mathrm{O}= \\
\mathrm{CO}_{2}+\end{array}$ \\
\hline
\end{tabular}


$\begin{array}{llllllll}\text { A10 gi|383505758 } & 5 & 2.03 & \text { elongation factor } & \mathrm{Tu}, \text { partial } & 43000 / 6.07 & 22315 / 4.93 & \text { Mitochondrion }\end{array}$ [Mycoplasma hyorhinis]

\begin{tabular}{|c|c|c|c|c|c|c|c|}
\hline A13 & gi|149031959 & 10 & 2.40 & $\begin{array}{l}\text { rCG50668, isoform CRA_c } \\
{[\text { Rattus norvegicus }]}\end{array}$ & $40080 / 5.11$ & $31075 / 5.14$ & Predicted protei \\
\hline A17 & gi|195554222 & 5 & 2.49 & 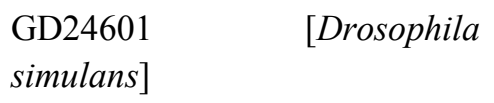 & $33035 / 6.27$ & $\begin{array}{l}11675 / 11.0 \\
5\end{array}$ & Predicted protei \\
\hline B2 & gi|149039794 & 6 & 2.48 & $\begin{array}{l}\text { heterogeneous } \\
\text { ribonucleoprotein } \quad \mathrm{K}, \text { isoform } \\
\text { CRA_b [Rattus norvegicus] }\end{array}$ & $59285 / 5.05$ & $43059 / 5.43$ & $\begin{array}{l}\text { ribonucleoprote } \\
\text { complex }\end{array}$ \\
\hline B3 & gi|149039794 & 7 & 1.92 & $\begin{array}{l}\text { heterogeneous } \\
\text { ribonucleoprotein } \quad \mathrm{K}, \text { isoform } \\
\text { CRA_b [Rattus norvegicus] }\end{array}$ & $58605 / 5.24$ & $43059 / 5.43$ & $\begin{array}{l}\text { ribonucleoprote } \\
\text { complex }\end{array}$ \\
\hline B5 & gi|51948418 & 6 & 3.00 & $\begin{array}{l}\text { elongation factor 1-gamma } \\
\text { [Rattus norvegicus] }\end{array}$ & $47005 / 6.19$ & $50371 / 6.31$ & $\begin{array}{l}\text { eukaryotic } \\
\text { translation }\end{array}$ \\
\hline B6 & gi $\mid 383505758$ & 3 & 2.35 & $\begin{array}{l}\text { elongation factor } \mathrm{Tu} \text {, partial } \\
\text { [Mycoplasma hyorhinis] }\end{array}$ & $45655 / 6.15$ & $22315 / 4.93$ & $\begin{array}{l}\text { elongation } \\
\text { complex } \\
\text { Cytoplasm }\end{array}$ \\
\hline B7 & gi|149041704 & 3 & $\infty^{f}$ & $\begin{array}{l}\text { isocitrate dehydrogenase } 3 \\
(\mathrm{NAD}+) \text { alpha, isoform } \\
\text { CRA_f [Rattus norvegicus }]\end{array}$ & $40454 / 5.90$ & $39409 / 5.87$ & Mitochondrion \\
\hline B8 & gi|6981146 & 4 & 1.74 & $\begin{array}{l}\text { L-lactate dehydrogenase } \mathrm{B} \\
\text { chain [Rattus norvegicus] }\end{array}$ & $37508 / 5.72$ & $36874 / 5.7$ & Cytoplasm \\
\hline
\end{tabular}

NADPH.

This protein promotes the GTPdependent binding of aminoacyl-tRNA to the A-site of ribosomes during protein biosynthesis

nucleic acid binding

nucleic acid binding

Probably plays a role in anchoring the complex to other cellular components

This protein promotes the GTPdependent binding of aminoacyl-tRNA to the A-site of ribosomes during protein biosynthesis

Catalytic activity Isocitrate + $\mathrm{NAD}^{+}=2$-oxoglutarate $+\mathrm{CO}_{2}$ $+$

$\mathrm{NADH}$.

Catalytic activity:(S)-lactate + $\mathrm{NAD}^{+}=$pyruvate $+\mathrm{NADH}$. 


\begin{tabular}{|c|c|c|c|c|c|c|c|c|}
\hline B11 & gi|7242160 & 2 & 1.69 & $\begin{array}{l}\text { nucleophosmin } \\
\text { norvegicus] }\end{array}$ & $35806 / 4.64$ & $32711 / 4.62$ & $\begin{array}{l}\text { Cytoplasm } \\
\text { Cytoskeleton } \\
\text { Nucleus }\end{array}$ & $\begin{array}{l}\text { Involved in diverse cellular } \\
\text { processes such as ribosome } \\
\text { biogenesis, } \\
\text { duplication, centrosome } \\
\text { chaperoning, histone assembly, } \\
\text { cell proliferation, and } \\
\text { regulation of tumor suppressors } \\
\text { p53/TP53 and ARF. }\end{array}$ \\
\hline B12 & gi|7242160 & 2 & $\infty^{\mathrm{f}}$ & $\begin{array}{l}\text { nucleophosmin } \\
\text { norvegicus] }\end{array}$ & $36044 / 4.86$ & $32711 / 4.62$ & $\begin{array}{l}\text { Cytoplasm } \\
\text { Cytoskeleton } \\
\text { Nucleus }\end{array}$ & $\begin{array}{l}\text { Involved in diverse cellular } \\
\text { processes such as ribosome } \\
\text { biogenesis, centrosome } \\
\text { duplication, protein } \\
\text { chaperoning, histone assembly, } \\
\text { cell proliferation, and } \\
\text { regulation of tumor suppressors } \\
\text { p53/TP53 and ARF. }\end{array}$ \\
\hline B13 & gi|257096637 & 4 & $\infty^{\mathrm{f}}$ & $\begin{array}{l}\text { RecName: Full=Elongation } \\
\text { factor 1-delta; Short=EF-1- } \\
\text { delta }\end{array}$ & $34317 / 6.23$ & $31425 / 4.94$ & $\begin{array}{l}\text { eukaryotic } \\
\text { translation } \\
\text { elongation factor } 1 \\
\text { complex }\end{array}$ & $\begin{array}{l}\text { EF-1-beta and EF-1-delta } \\
\text { stimulate the exchange of GDP } \\
\text { bound to EF-1-alpha to GTP }\end{array}$ \\
\hline B14 & gi|6978503 & 5 & 1.79 & $\begin{array}{l}\text { annexin } \quad \text { A3 } \\
\text { norvegicus] }\end{array}$ & $27397 / 5.31$ & $36528 / 6.04$ & $\begin{array}{l}\text { axon/dendrite/neuro } \\
\text { nal cell body }\end{array}$ & $\begin{array}{l}\text { Inhibitor of phospholipase } \mathrm{A} 2 \text {, } \\
\text { also possesses anti-coagulant } \\
\text { properties }\end{array}$ \\
\hline B15 & gi|223365745 & 14 & 1.56 & $\begin{array}{l}\text { Chain A, Crystal Structure } \\
\text { Analysis Of The Sodium- } \\
\text { Bound Annexin A4 At } 1.58 \\
\text { A Resolution }\end{array}$ & $24398 / 5.11$ & $36480 / 5.43$ & No information & $\begin{array}{l}\text { Calcium/phospholipid-binding } \\
\text { protein, which promotes } \\
\text { membrane fusion and is } \\
\text { involved in exocytosis }\end{array}$ \\
\hline B18 & gi|149049976 & 6 & $\infty^{\mathrm{f}}$ & $\begin{array}{l}\text { rCG37103, isoform CRA_b } \\
{[\text { Rattus norvegicus }]}\end{array}$ & $15762 / 5.07$ & $15007 / 5.09$ & No information & \\
\hline
\end{tabular}

A: Down-regulated proteins, B: Up-regulated proteins.

${ }^{a}$ Spot no. is the unique sample spot protein number that refers to the labels in Fig. 6. 
${ }^{\mathrm{b}}$ Accession no. is the MASCOT result of MALDI-TOF/TOF searched from the NCBInr database.

${ }^{c} \mathrm{X}$-fold is the level of up-regulation or down-regulation of protein spots after DATS treatment.

${ }^{\mathrm{d}} \mathrm{MW}$ is molecular weight.

${ }^{\mathrm{e}} \mathrm{pI}$ is isoelectric point.

${ }^{\mathrm{f}}$ The fold changes are $\infty$, indicating that the protein spots were only observed before DATS treatment. 
Fig. 1. DATS inhibits HSC cell proliferation by MTT or BrdU assays. HSCs (5000 cells per well) were plated into a 96-well plate. Cells were incubated with $10 \%$ FBS, $0.1 \%$ DMSO, $12 \mu \mathrm{g} / \mathrm{mL}$ DATS or $24 \mu \mathrm{g} / \mathrm{mL}$ DATS. MTT and BrdU assays were performed after the cells were cultured for $6 \mathrm{~h}, 12 \mathrm{~h}$ and 24 h respectively. $n=3 .{ }^{*} P<0.05$ and ${ }^{* *} P<0.01$, compared with $0.1 \%$ DMSO.

Fig. 2. Representative images (magnification $\times 200$ ) of apoptosis in HSCs. The cells were treated with 10\% FBS alone, 0.1\%DMSO, $12 \mu \mathrm{g} / \mathrm{mL}$ DATS and $24 \mu \mathrm{g} / \mathrm{mL}$ DATS for $6 \mathrm{~h}(\mathrm{~A}), 12 \mathrm{~h}(\mathrm{~B})$ and 24 h (C), respectively. Cells were stained with or without Hoechst 33342.

Fig. 3. Transmission electron microscopy (TEM) showed morphological changes of apoptosis in HSCs. Cells were incubated with $0.1 \%$ DMSO or $24 \mu \mathrm{g} / \mathrm{mL}$ DATS for $24 \mathrm{~h}$. A) Normal HSCs ( $\times 9700)$; B) Chromatin condensation and margination inside the nuclear membrane of the cells treated with $24 \mu \mathrm{g} / \mathrm{mL}$ DATS $(\times 5800)$; C) Nuclear chromatin condensation and shrinkage in the cells treated with $24 \mu \mathrm{g} / \mathrm{mL}$ DATS $(\times 5800)$; D) Reduced nuclear volume, cleavage into multiple dense bodies, and apoptotic body formation with complete membrane framework in the HSCs treated with $24 \mu \mathrm{g} / \mathrm{mL}$ DATS $(\times 5800)$.

Fig. 4. DATS treatment induced time-dependent apoptosis in HSCs. (A) Flow cytometry analysis of HSCs treated with DMSO (control) or $24 \mu \mathrm{g} / \mathrm{mL}$ DATS for 6,12 and $24 \mathrm{~h}$. The flow cytometry was performed using a double-staining method with FITC-conjugated annexin-V and PI. (B)

Quantitation of apoptotic cells. Results are mean $\pm \operatorname{SD}(n=3) .{ }^{*} P<0.05$ and ${ }^{* *} P<0.01$, compared to DMSO treated control. 
Fig. 5. Effects of DATS on cell cycle regulation in HSCs. (A) Representative flow cytometry analysis. The HSCs were treated with DMSO (control) or $24 \mu \mathrm{g} / \mathrm{mL}$ DATS for 6,12 and $24 \mathrm{~h}$. (B) Quantitative analysis of the percentage of cells in each phase of the cell cycle. Results are mean \pm SD $(n=3) .{ }^{*} P<0.05$ and ${ }^{* *} P<0.01$, compared to DMSO treated control.

Fig. 6. Representative 2-DE gel analysis of differential protein expression in HSCs. The cells were treated with $0.1 \%$ DMSO (A) or $24 \mu \mathrm{g} / \mathrm{mL}$ DATS (B) for $12 \mathrm{~h}$. Whole soluble proteins from HSCs were separated with 2-DE and visualized using silver staining. The protein spots altered by MCLR exposure are labeled with numbers. The molecular weights (MW) and pI scales are indicated. Each gel is representative of three independent replicates. 
A

MTT assay

$0.1 \%$ DMSO
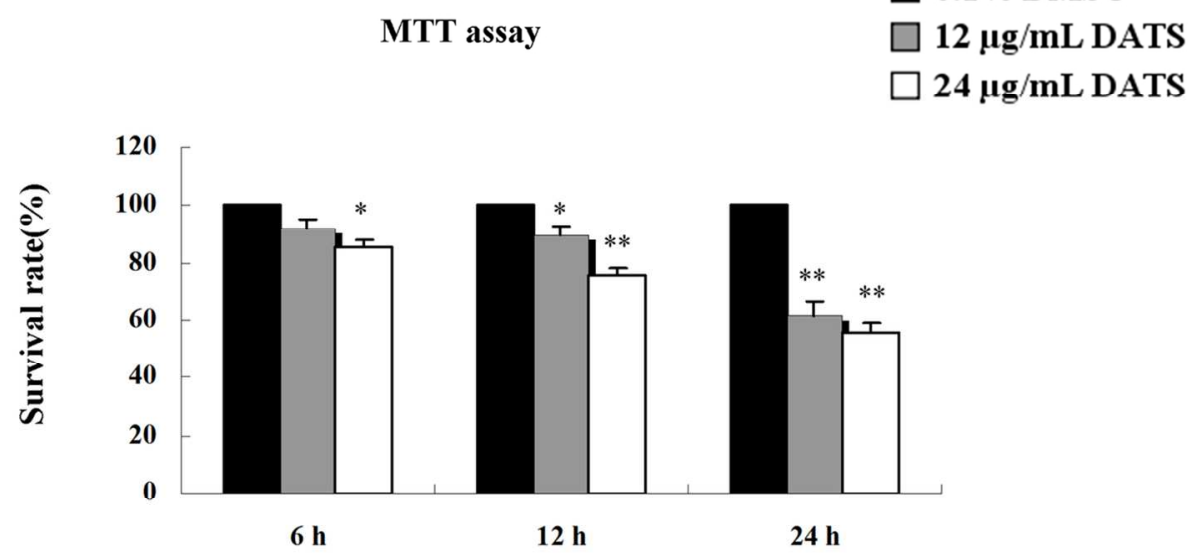

B

Brdu assay

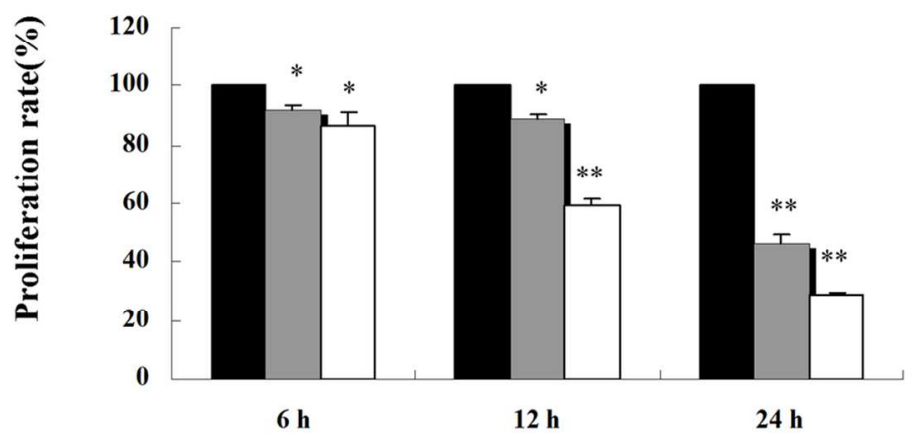

Fig. 1. DATS inhibits HSC cell proliferation by MTT or BrdU assays. HSCs (5000 cells per well) were plated into a 96-well plate. Cells were incubated with $10 \%$ FBS, $0.1 \%$ DMSO, $12 \mu \mathrm{g} / \mathrm{mL}$ DATS or $24 \mu \mathrm{g} / \mathrm{mL}$ DATS. MTT and BrdU assays were performed after the cells were cultured for $6 \mathrm{~h}, 12 \mathrm{~h}$ and $24 \mathrm{~h}$ respectively. $\mathrm{n}=$ 3. $* \mathrm{P}<0.05$ and $* * \mathrm{P}<0.01$, compared with $0.1 \%$ DMSO.

$114 \times 106 \mathrm{~mm}(300 \times 300$ DPI $)$ 


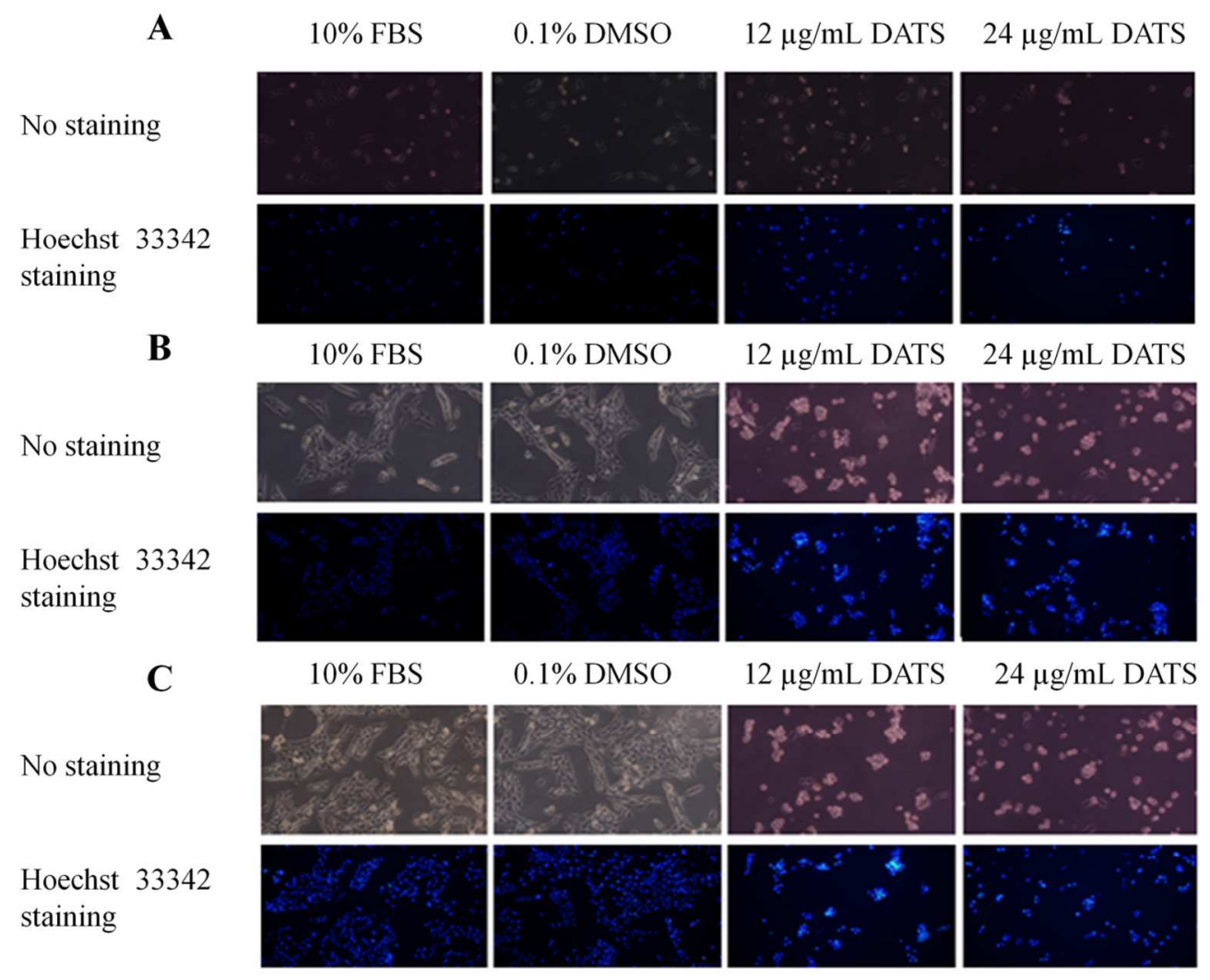

Fig. 2. Representative images (magnification $\times 200$ ) of apoptosis in HSCs. The cells were treated with $10 \%$ FBS alone, $0.1 \%$ DMSO, $12 \mu \mathrm{g} / \mathrm{mL}$ DATS and $24 \mu \mathrm{g} / \mathrm{mL}$ DATS for $6 \mathrm{~h}(\mathrm{~A}), 12 \mathrm{~h}$ (B) and $24 \mathrm{~h}$ (C), respectively. Cells were stained with or without Hoechst 33342.

$111 \times 91 \mathrm{~mm}(300 \times 300$ DPI $)$ 

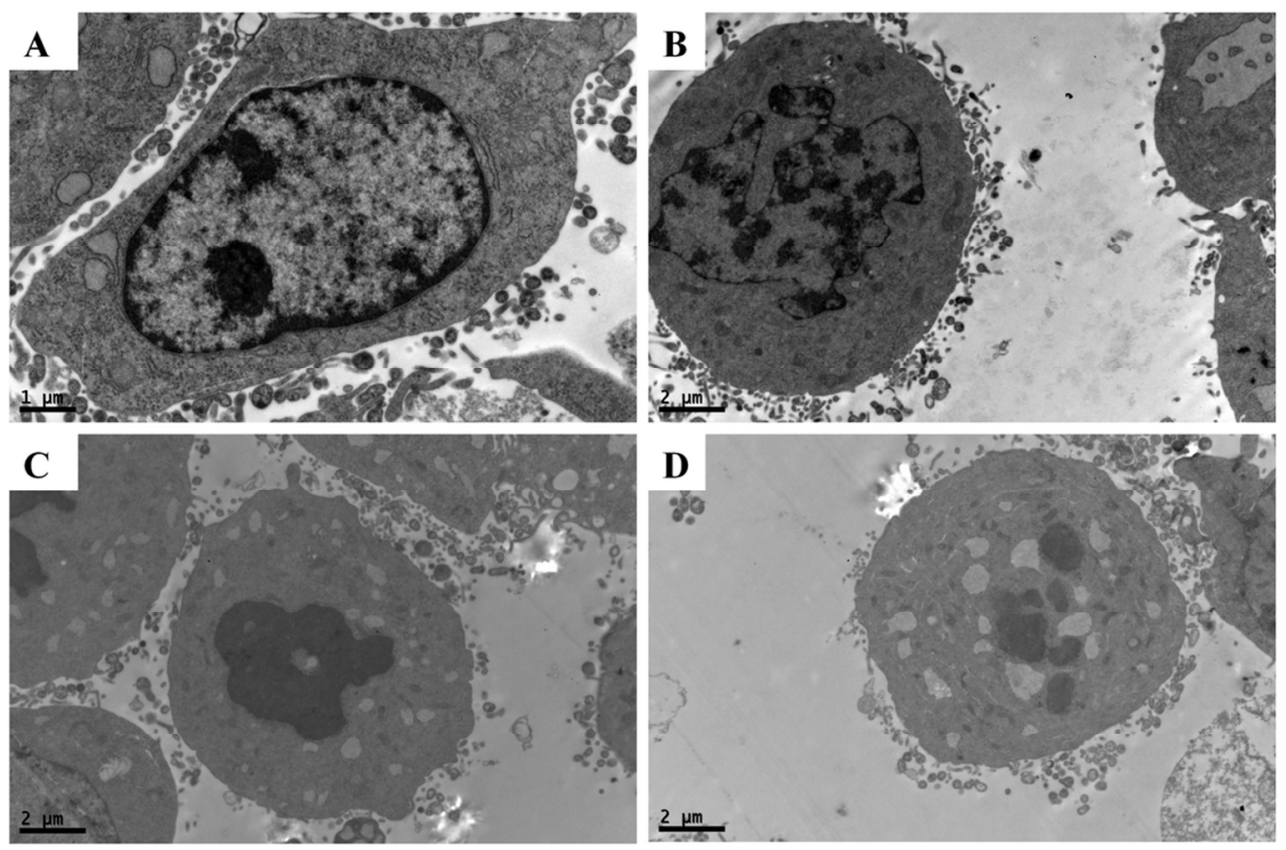

Fig. 3. Transmission electron microscopy (TEM) showed morphological changes of apoptosis in HSCs. Cells were incubated with $0.1 \%$ DMSO or $24 \mu \mathrm{g} / \mathrm{mL}$ DATS for $24 \mathrm{~h}$. A) Normal HSCs $(\times 9700)$; B) Chromatin condensation and margination inside the nuclear membrane of the cells treated with $24 \mu \mathrm{g} / \mathrm{mL}$ DATS $(\times 5800)$; C) Nuclear chromatin condensation and shrinkage in the cells treated with $24 \mu \mathrm{g} / \mathrm{mL}$ DATS $(\times 5800)$; D) Reduced nuclear volume, cleavage into multiple dense bodies, and apoptotic body formation with complete membrane framework in the HSCs treated with $24 \mu \mathrm{g} / \mathrm{mL}$ DATS $(\times 5800)$.

$97 \times 63 \mathrm{~mm}(300 \times 300$ DPI $)$ 
A
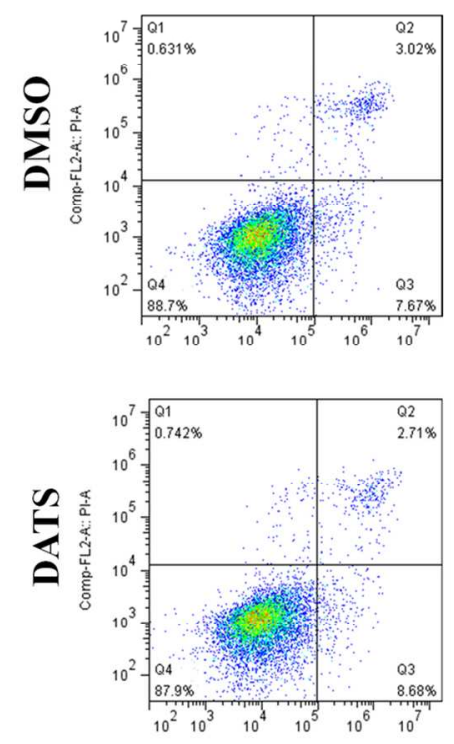

B

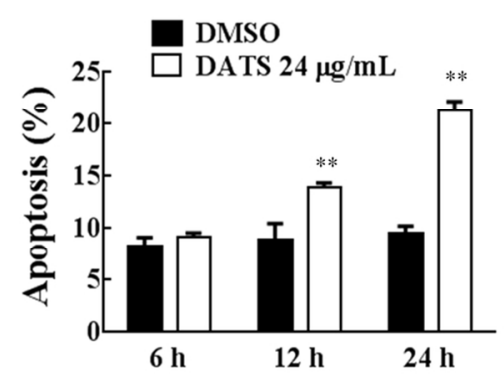

$12 \mathrm{~h}$
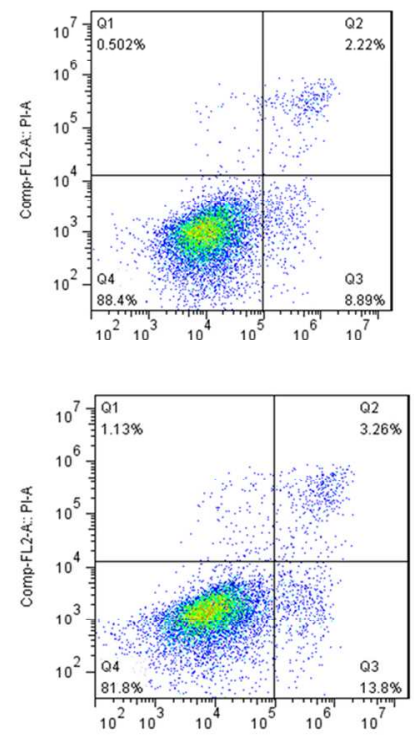

Comp-FL1-A: Annexin VFITC-A
$24 \mathrm{~h}$
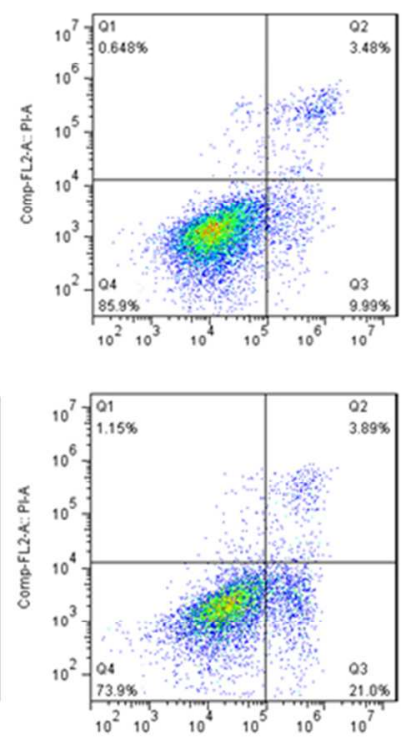

Comp-FL1-A: Annexin V FITC.A

Fig. 4. DATS treatment induced time-dependent apoptosis in HSCs. (A) Flow cytometry analysis of HSCs treated with DMSO (control) or $24 \mu \mathrm{g} / \mathrm{mL}$ DATS for 6,12 and $24 \mathrm{~h}$. The flow cytometry was performed using a double-staining method with FITC-conjugated annexin-V and PI. (B) Quantitation of apoptotic cells. Results are mean $\pm S D(n=3) . * P<0.05$ and $* * P<0.01$, compared to DMSO treated control.

$$
113 \times 108 \mathrm{~mm} \text { ( } 300 \times 300 \text { DPI) }
$$


A
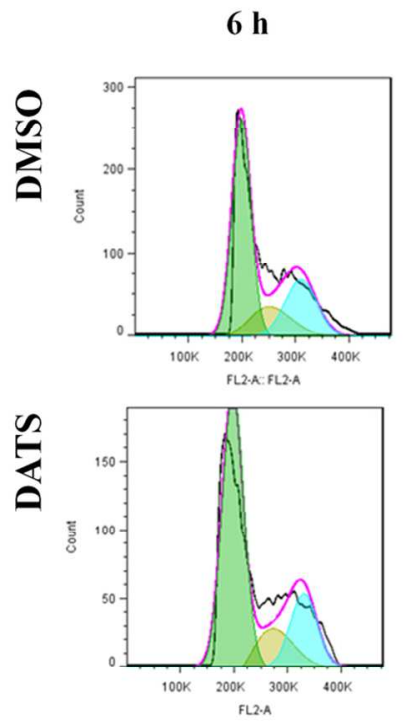

B

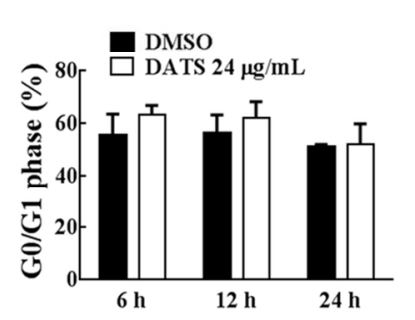

$12 \mathrm{~h}$
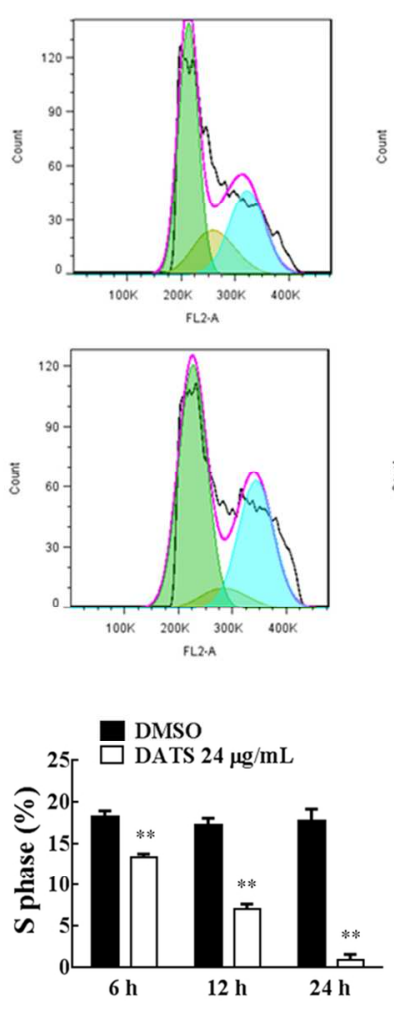

$24 \mathrm{~h}$
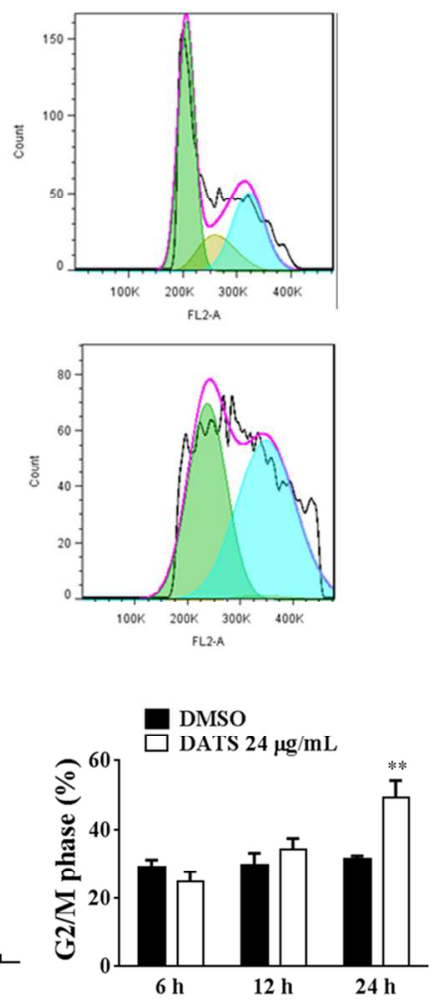

Fig. 5. Effects of DATS on cell cycle regulation in HSCs. (A) Representative flow cytometry analysis. The HSCs were treated with DMSO (control) or $24 \mu \mathrm{g} / \mathrm{mL}$ DATS for 6, 12 and $24 \mathrm{~h}$. (B) Quantitative analysis of the percentage of cells in each phase of the cell cycle. Results are mean $\pm S D(n=3)$. *P $<0.05$ and $* * P<$ 0.01 , compared to DMSO treated control.

$110 \times 91 \mathrm{~mm}(300 \times 300 \mathrm{DPI})$ 


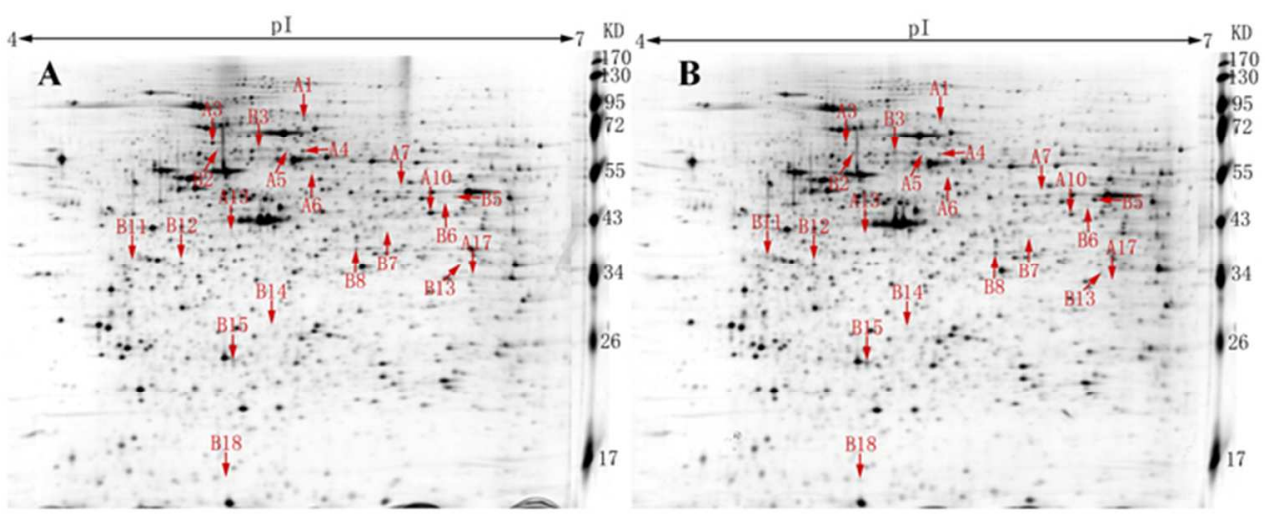

Fig. 6. Representative 2-DE gel analysis of differential protein expression in HSCs. The cells were treated with $0.1 \%$ DMSO (A) or $24 \mu \mathrm{g} / \mathrm{mL}$ DATS (B) for $12 \mathrm{~h}$. Whole soluble proteins from HSCs were separated with 2-DE and visualized using silver staining. The protein spots altered by MCLR exposure are labeled with numbers. The molecular weights (MW) and pI scales are indicated. Each gel is representative of three independent replicates.

$61 \times 24 \mathrm{~mm}(300 \times 300 \mathrm{DPI})$ 